\title{
Critical Discourse Analysis and Rhetorical Tropes in Donald Trump's First Speech to the UN
}

\author{
Mahdi Derakhshani \\ Department of English, Islamic Azad University, Shabestar Branch, Shabestar, Iran \\ Shatha Naiyf Qaiwer \\ Department of English, College of Education for Women, University of Baghdad, Iraq \\ Bahram Kazemian* \\ Department of English, Islamic Azad University, Tabriz Branch, Tabriz, Iran \\ Shafigeh Mohammadian \\ Independent Researcher, Tabriz, Iran
}

\begin{abstract}
Language and politics go hand in hand and learning and comprehending political genre is to learn a language created for codifying, extending and transmitting political discourse in any text/talk. Drawing upon the theoretical framework of Fairclough's CDA and Rhetoric, the current study aims at investigating Donald Trump's First Speech, from the point of frequency and functions of some rhetorical strategies (Parallelism, Anaphora and the Power of Three, Antithesis and Expletive, etc.), Nominalization, Passivization, We-groups and Modality as well as Lexical and Textual Analysis, presented to the UN delivered on Sep. 19, 2017. Specifically, the study seeks to determine: (1) how President Trump succeeded in conveying his notions and assumptions to his intended audience, and in convincing and negotiating, (2) how he attempted to explicitly and implicitly pass his attitudes on his targets, and (3) how those orientations, intended notions and assumptions were seamlessly presented to his addressees in discoursal and lexico-grammatical levels; (4) and finally in this underlying trend how he achieved his own ends. The results of the study hope to enhance reading comprehension and writing in academic registers for EFL/ESL students.
\end{abstract}

Index Terms - CDA, rhetoric, passivization, modality, lexical \& textual analysis, unification strategy, power of three, antithesis

\section{OVERVIEW}

Language plays a vital role in the transfer of orators' forethought and pre-determined notions to the crowd. Language is not independently powerful; it obtains power through the powerful use of pundits and politicians etc. to provoke, prevail, and persuade the audience toward the intended goals and meanings. Kazemian and Hashemi (2014) contend that "power is signified, for example, by rhetorical and grammatical forms within a text or a text's genre". This underlines a growing need for scrutinizing the language use of those prominent people critically and rhetorically.

Schiffrin, et al. (2003) postulate that discourse has broadly been construed as anything above the sentence; for others, the study of discourse is the study of language use, though. Discourse refers to modes of speaking and writing whereby interactants engaged in the acts of communication adopt particular attitudes towards areas of socio-cultural activity (Schiffrin, et al. 2003). Discourse Analysis (DA) is a rapidly growing and evolving field. Considering its diverse definitions, it is no surprise that the terms discourse and DA have various meanings to teachers-researchers in various fields. DA is generally characterized by scholars as the study of usage of languages in text/talk and its contextual meaning, whereas CDA is the analytical discourse as a research to investigate the social practice of domination, power abuse by text and talk in a socio-political context. CDA views discourse as a form of social practice (Van Dijk, 2001). There are various definitions for CDA by salient scholars; those definitions might seem different on the surface but all unanimously concur on the fact that CDA is an analytical approach for language in use.

To Fairclough (2006), CDA is an increasing interdisciplinary analytical movement which sifts through the association between discourse and power, and it specifically inspects the way in which "authority, dominance and social inequality are constructed, sustained, reproduced and resisted in the discourse of written texts and spoken words"

\footnotetext{
*Corresponding author: bahram_kazemian@yahoo.com https://orcid.org/0000-0001-8957-821X
} 
(Kazemian \& Hashemi, 2014; Kazemian et al., 2021). CDA targets to unload the down-to-earth social and cultural notions which are deeply lodged in 'all forms of language' that we exert (Kazemian et al., 2021).

Fairclough's $(1989,2003)$ approach to CDA is unique, the focus of this study, in that he deals with the central focus on the linguistic investigation of textual materials and has established linguistic devices probing textual forms and structures. Fairclough's procedure is of great value in essence as it narrows the divergence between the structural components of language and the extrinsic communal world it struggles to exhibit through which a deeper comprehension of discourse can be attained. To substantiate the linguistic relationship to such subjectivity, Fairclough adopts the procedure triggered by Halliday (1994) as Systemic Functional Linguistics (SFL) to dissect discourse at the lexico-grammatical level. The interaction between discourse and social engagements can be perceived through a grammatical inspection of structural components (Kazemian \& Hashemi, 2014). To Fairclough (1989), there is a significant correlation between society and discourse to complement each other well. To him, discourse molds the way people think and the linguistic properties as vehicles bear creed, assumptions, and perceptions of the social world.

Whereas CDA's primary focus is on language in its socio-cultural context, the ideological presumptions formulated through interaction, texts, and linguistic investigation of textual materials, rhetorical analysis restricts its prime focus to political interplay and probes "to find patterns of goals, interests and joint assumptions underlying persuasive actions" (Jorgensen \& Phillips, 2002, p. 125).

Technically, Rhetoric is the art of discourse, wherein a rhetorician struggles to brief, exhort or stimulate specific audiences in specific situations. In rhetoric, rhetorical apparatus (resources of language, or stylistic device) is a method that rhetoricians deploy to express a message or meaning to the listener or reader with the aim of convincing and inciting him/her towards considering a subject/s from a distinctive aspect and outlook, exploiting sentences engineered to persuade or provoke an emotional display of a given mindset or action. The term rhetoric in this sense, the focus of this study, proposes an analytical toolkit to inquire into and ruminate on how to impart itself appropriately and adequately in association with the subject matter of text/talk, and the crowd, and to draw upon practices to distinguish the connections between contexts and texts (Jost \& Olmsted, 2004, p. 25).

\section{A. Statement of the Problem and the Purpose of the Study}

Every text/talk text incorporates some lexico-grammatical components that constitute its existence as a meaningful context. This meaningful context contains some covert, implicit presumptions and implications. To van Dijk (2012) "discourses are like icebergs. Only a minor part of their meaning is 'visible' as explicit propositions expressed in their sentences. The major parts of their meaning remain implicit, namely as implied propositions" (p. 596). Thusly, we must be attentive while we read, sift through or inquire into political discourse to explore evidence of persuasive, purposive and eclectic deployment of "words and expressions, or even of contextual, lexico-grammatical, rhetorical tropes and so on" (Kazemian, et al., 2021). Knowing rhetorical devices and CDA strategies along with their respective implications and the way to unpack those implied expressions, and strategies can be very effective for EFL and ESL learner's proficiency in academic registers at various levels; it can develop reading comprehension in EFL and ESL students in academic registers as well.

Regarding the absence of studies in Donald Trump's First Speech to the UN, the aim of this study is to investigate Donald Trump's First Speech to the UN, about 4500 words, from the point of frequency and functions of some rhetorical and critical strategies as well as Lexical and Textual Analysis to reveal their implicit and explicit meanings, and structures as well as to grasp and disclose the effective and dominant principles and tropes utilized in his speech. Fairclough's CDA framework is used to unravel the speaker's adroit and skillful employment of these devices in the speech which are bound up with his overall political orientations. The study seeks to determine how President Trump succeeded in conveying his notions and assumptions to his intended audience; additionally, the study scrutinized the corpus to unpack how he attempted to explicitly and implicitly pass his attitudes on his targets.

\section{B. Significance and Justification of the Study}

According to Van Dijk (2013), critical discourse studies do not privilege a specific analytical model or believe in the necessity of such a unified method. Researchers working within this school are free to locate or design an appropriate method for their study depending on its aims, research questions, and the type of data. For this study, we accordingly draw on some CDA strategies and rhetorical devices for the first phase of the research to show how Mr. Trump made use of given devices and resources in order to smoothly present and convey his intended ideologies and assumptions to a convincing representation of the deal to the American people as well as to the rest of the world.

Considering the fact that most students in academic registers have reading comprehension problems in various discourses (Johnson, 1981; Atai \& Nazari, 2011; Afshar \& Movassagh, 2016), this study hopes to smooth the path for those students interested in comprehending political or other academic discourses. Most academic students are seemingly oblivious to the fact that nearly all political texts/talks contain hidden assumptions and ideologies which are deliberately engineered for public consumption. By knowing rhetorical and CDA strategies, academic students can be equipped to deal with and take into account those hidden ideologies and intentions which are beneath the surface of any political texts/talks. They will remain vigilant at all times to hold their attention to invisible and implicit parts of any political text/talk. 
The selection of the speech is grounded in its deft political rhetoric and oratory; the benchmarks for choosing these devices and tropes are as follows: Principally, agentlessness (passive voices) leaves an agent fuzzy and is chiefly deployed to depict ambiguity and equivocation - as true for nominalization. Then, an insight into the essence and the functions of rhetorical devices in political discourse can assist instructors and scholars, to give overarching and fathomable presentations of these strategies; knowing these tropes and devices can aid readers and students to pinpoint their considerable significance for perusing and comprehending political speeches as well. The main pedagogical goals of this study are, firstly, raising the consciousness of EFL and ESL students, and instructors in academic registers with regard to the role of lexico-grammatical and rhetorical expressions as well as implied assumptions in reading and comprehending political discourse. Then, it can help students to identify those implicit messages and implications in a clause and in different political text/talk in particular, so that, equipped with such political awareness, their reading comprehension could be assisted. Eventually, it is to develop students' awareness of the characteristics of political written/spoken discourses.

\section{LITERATURE REVIEW \& THEORETICAL FRAMEWORKS}

\section{A. CDA \& Its Pertinent Literature}

As mentioned above, the primary linguistic approach in language studies is the analysis of discourse. Critical Discourse Studies (thereafter, CDS) as a school of discourse analysis provides researchers with a critical attitude towards the relationship between discourse and society and a set of guidelines about how this mutuality of discourse (text) and society (context) should be taken into account. CDS, on the one hand, aims at showing how discourse constructs social structures through representing the world in a particular way, and on the other, it demonstrates that this particular representation is itself under the influence of social structures like power relations and ideologies (Fairclough, 1995). Fairclough (1989) specified that CDA is a critical tool for analysis; it is argued that:

Discourse is shaped by situations, institutions and social structures, but it also shapes them. In other words, is socially constitutive as well as socially shaped: it constitutes situations, objects of knowledge, and the social identities of and relationships between people and groups of people. It is constitutive both in the sense that it contributes to transforming it (Fairclough \& Wodak, 1997, p. 258).

There seems to be a growing body of studies on CDA as follows. Kazemian and Hashemi (2014) proposed an integrated procedure by investigating political discourse through the lenses of two frameworks viz CDA \& Rhetoric plus Nominalization in SFL. In another research, Kazemian \& Hashemi (2017) have probed ideological assumptions lodged in three speeches by Mr. Obama; the analysis is based on Fairclough's perspectives of ideology and significance of inspecting the grammatical prospects of discourse, Hallidayan Grammatical Metaphor (GM) in SFL and some rhetorical strategies (Kazemian, et al., 2021). In some other veins, Ali and Kazemian (2015) analyzed a speech by Liaquat Ali Khan in light of Van Dijk's socio-cognitive framework to emphasize the key aspects of discourse construction and perception. In another study, Ali, et al. (2015) explored a reading text 'Pakistan Zindabad' to recognize and address issues and display the gap and obliviousness on the part of instructors and learners regarding the $\mathrm{CDA}$ of the text in the context of reading classroom. In surveying the current annals of literature, some other remarkable inquiries was found which scrutinize a wide variety of political text/talk in light of CDA to point out numerous strategies applied by eloquent rhetoricians and politicians, and to demonstrate how they make political discourse convincing, consequential, entrancing, and obscure, and how they convey their intended objectives to the crowd as well (Hussein, 2016; Amoli, 2016; Skarp, 2016; Carreon, \& Svetanant, 2017; Gill \& Kausar, 2017; Albtoush \& Sahuri, 2017a, b; Kazemian et al., 2021 etc.). Prior studies contributed to focus on some other discourses and genres. This study is unique in the sense that it struggles to narrow the gap among formers surveys by looking into Donald Trump's First Speech to the UN through the lenses of CDA strategies, Rhetorical tropes and Nominalization to reveal its implicit and explicit meanings and structures as well as to grasp and disclose the effective and dominant principles and tropes utilized in his speech.

\section{B. Rhetoric and Its Relevant Literature}

To Corbett (1990), Rhetoric is "an art that aims to improve the capability of speakers that attempt to inform, persuade or motivate audiences in specific situations" (p. 1). It is the skill to use language more impressive and persuasive. Moreover, Leech (1983) clearly delineates rhetoric as "the effective use of language in its most general sense, how it is applied in everyday conversation and public speaking" (p. 15). So, the purpose of rhetoric is not plainly to accomplish persuasiveness, but rather "to uncover the means of approaching as near such success as the circumstances of each particular case" (Kazemian et al., 2021).

In all political systems whether monocratic or democratic, leaders need people to accept and believe in the virtuousness of their leadership. Even totalitarian regimes cannot rely only on coercion and need to employ some forms of 'soft power' to legitimize themselves (Althusser, 1971; Gramsci, 1971). Performing in language is one of the most effective means by which leaders try to legitimize their leadership and mobilize their followers (Charteris-Black, 2005). Legitimization and mobilization as important political goals are also the concern of two language-oriented fields: CDA and Classical Rhetoric (Fairclough \& Fairclough, 2013; Goddard \& Krebs, 2015; Wodak, Angouri, \& Vaara, 2014). 
While CDA is concerned with the notion of discourse representation and how it can help achieve legitimation to serve or resist power relations, rhetoric deals with how that representation is made persuasive in order to make people believe in an idea or person and to mobilize them to take specific actions. Rhetorical analysis therefore is "an effort to understand the whole of a message and the way the message has been constructed for the purpose of persuasion" (Bazerman \& Prior, 2003, p. 282). This means that rhetoric can enrich CDA by providing information about the mechanisms of a persuasive representation. CDA's main concern is answering broader questions regarding what representation of reality a specific discourse offers; and whose interests it serves (Bazerman \& Prior, 2003). Rhetoric can help identify how this representation of reality is constructed to be appealing to its audience. By bringing these two frameworks together, the researchers aim to show how Mr. Trump presents a version of reality that is in line with his interests and ideologies and, at the same time, persuasive to his audience.

Rhetoric and Rhetorical devices have been used widely in linguistic studies whether in DA, CDA, or in political and law discourses, literature or language learning and teaching. The focus is various from one study to another in terms of what of the various CDA and rhetorical devices to be analyzed. Reviewing the annals of literature, recent years have witnessed increased attention being given to Rhetoric and political text/talk as follows. A survey of investigations from the perspective of CDA, SFL and rhetoric by Kazemian and Hashemi (2014) and Kazemian et al. (2021) was made to perform and explore Barack Obama's 2012 five speeches and Mr. Khamenei's 2 letters to the youth in the Occident. The studies contributed to find out the frequency and functions of Burke's Identification theory, GM, Rhetorical tropes, Passivization, Modality etc. Zhou and Kazemian (2015) made a study based on Burkean rhetorical theory and Identification to dissect John F. Kennedy's Inaugural Address. An analysis of rhetorical devices in Hillary Clinton concession speech to reveal their respective functions was applied by Taping, Juniardi \& Utomo (2017). Revising recent annals of literature in rhetoric, there are other studies that adopted Rhetoric and its devices in various discourses and text/talk (Bull \& Wells, 2002; Flowerdew, 2002; Bizzell, 2003; Murphy, 2003; Sinha\& Jackson, 2006; Lillian, 2008; Rex, 2011; Li \& Chen, 2015; Bull, 2016; ).

\section{METHODOLOGY}

It is assumed that "familiarity with context can assist readers in comprehending coherent relations across text/talk" (Kazemian \& Hashemi, 2014). To date few studies have embarked on analyzing Donald Trump's first speech to the UN based on CDA and rhetorical devices. The current study followed a qualitative approach to analysis. The method of analysis was top-down, applying some rhetorical devices (Parallelism \& Anaphora, the Power of Three \& Amplification, Antithesis \& Expletive, and Rhetorical questions), and some CDA strategies (Passivization \& Nominalization, We-groups and Modality) presented by Fairchlough (1989) as well as Lexical and Textual Analysis.

\section{A. Corpus}

Due to the paramount importance of selecting authentic and a native speech in political genres, an effort was made to choose the US president's speech to the UN on the basis of its recent delivery, skillful political rhetoric and oratory. For the purposes of this study and due to its international political salience, the speech, approximately 4500 words, is selected to pinpoint and analyze the frequency and functions of those devices and strategies. The speech was delivered on Sep. 19, 2017; the full transcript of the speech is available in the following link (https:/www.independent.co.uk/news/world/americas/us-politics/trump-un-speech-read-in-full-transcript-north-koreageneral-assembly-a7956041.html).

\section{B. Procedure}

The analysis began by perusing the given speech several times by the researchers and a colleague, specialized in CDA and Rhetoric. Primarily, it was scrutinized by the researchers in order to identify tokens of frequent and possible rhetorical devices and CDA strategies used by Mr. Trump. In the first phase of the analysis, the researchers perused the speech to spot probable devices and strategies; then, each instance of chosen devices and strategies was counted, classified and tabulated based on their frequency in the speech; each of which is explicated in the next chapter. After about a two-month intermission, 'coding reliability' was attested by a second probe by the researchers, and any divergence in differentiating between rhetorical tropes and CDA strategies was recorded and fully settled. 'Cohen's Kappa coefficient' $(\kappa)$ was employed to beckon the amount of intra-coder reliability (a statistic which measures interrater agreement for qualitative (categorical) items, and the attained index was 0.91 . Kappa values ranging from -1 to +1 ; a value of 1 depicts total accord, and a value between 0.80 and 1 denotes very nice accord. Furthermore, a fraction of the corpus was chosen and perused by the colleague to check the accuracy of recognition of rhetorical devices and CDA strategies and to aid boosting the credibility of the inspections and the findings. Cohen's Kappa coefficient signified an index of 0.80 . In the second phase of the analysis, the researchers extracted the functions of those chosen devices and strategies used in each category by analyzing the lexico-grammatical contexts in which they occurred. Eventually, the corpus was critically analyzed and concentrated on more detailed points in terms of Lexical and Textual Analysis. The design of the present study is descriptive-analytic which focused on the frequency of occurrences of CDA strategies and Rhetorical tropes along with their respective functions in the speech. 


\section{DATA ANALYSIS AND DisCUSSION}

\section{A. CDA Strategies}

The exemplified and dominant featured CDA strategies in this study are passivization and nominalization, unification strategy (we-groups), and Modality, etc. each of which will be discussed in the following.

\section{Modality (Modal Verbs)}

Eggins's (2004) and Renkema's (2009) maintain that modal verbs enable language users, rhetoricians, and orators to convey and meekly impose their notions and ideologies to the audience. Modal verbs are utilized along with other verbs to articulate beliefs and perceptions such as probability, permission, prohibition, obligation, or intention with high, median, and low values as in Table 4.1. More schematically, modality with a highly functional mood paradigm is asserted in all languages through "either grammatical mood or modal systems (or both), and it is the degree of certainty about an incident, action or a state of affairs" (Kazemian \& Hashemi, 2014). To Mortelmans (2010), the English modal verbs are essentially involved with the degree of prospect, or the degree of individual obligation or engagement of the speaker toward the truth of a proposition. The English modal verbs, then, are regarded as making up the grammatical classification that is precisely related to the semantic classification of force dynamics, as such, the modal verbs are the 'grammaticalized encodings' of multitudinous forms in which entities communicate concerning forces and barriers. Fairclough (1989) argued that Modals are engaged with orators' authority as well; he views modality from two perspectives, on the basis of what aspect the authority is aligned with. Basically, relational modality (the focus of this study) is engaged upon the status of the authority of one person pertaining to others. Second, expressive modality is construed "as a matter of a speaker or writer's authority regarding the truth or possibility of a depiction of a reality" (Kazemian \& Hashemi, 2014). Relational modality is determined by modal auxiliary verbs such as might, must, would, can, ought to etc., as follows embraced from Halliday (1994) and Halliday \& Matthiessen, (2004):

\begin{tabular}{|c|c|c|c|}
\hline & Low politeness & $\begin{array}{c}\text { TABLE } 4.1 \\
\text { MODALITY VALUES } \\
\text { Median politeness }\end{array}$ & High politeness \\
\hline Positive (P) & Can, may, could, might & Will, would, should, shall & Must, ought to, need, has/had to \\
\hline Negative $(\mathbf{N})$ & needn't, need to, have to & Won't, wouldn't, shouldn't & $\begin{array}{l}\text { Mustn't, oughtn't to, can't, couldn't, mayn't, } \\
\text { mightn't, hasn't/hadn't to }\end{array}$ \\
\hline
\end{tabular}

Modal auxiliaries are implied instruments of modality of probability and necessity with high, median and low values. As table 4.1 manifests, high standards of modals include had to, need, must, and ought to plus their negative forms; median standard of modals accommodates will, should, and would etc.; and could, might, may, and can and the like are of low standard. Fairclough (2003) contends that with respect to grammatical options, a fundamental aspect of the inquiry draws in investigating modality which symbolizes viewpoints into commitments to truth, obligation and necessity. Consider the following excerpts from the speech:

1) If we desire ..., then we must fulfill our sovereign duties to .... We must protect our nations, ...... We must reject threats to sovereignty ..... We must uphold .....

2) We cannot let a murderous regime continue these destabilizing activities while building dangerous missiles, and we cannot abide by an agreement .....

The modal (must) is employed four times in example 1 and the modal (cannot) is applied twice in the example 2 which are enunciating deep conviction based on inference or deduction from proof; they exhibit commitment and obligation, in other words, authority's points of view obligate the addressees to do so. Thusly, obligation can be perceived as an unavoidable assignment or necessity achieved by must, and has (got) to; "the modal verb 'must' can have the force of a direct command" (Kazemian \& Hashemi, 2041). This force emanates from the fact that in definite cultural contexts, the orator has power and control over the crowd, and the orator takes the accountability for the action being carried out. The use of 'must', as signifying a real-world force imposed by the orator, impels the audience unquestioning obedience and to do the action or lead onto doing it stated in text/talk.

By using high negative modality (example 2) (cannot: denoting obligation), the speaker makes an effort to probably tempt and convince the crowd to pass a resolution calling for a ban to that Regime, otherwise, they will be accused of being incompetent and inept to do so. In the example (1), by dint of must, the speaker instills his attitudes and conceptualizations explicitly and then implicitly into the audience, as if "he is dictating and imposing what he wants the audience to do where it seems that they cannot help defying but agree with him" (Kazemian \& Hashemi, 2014).

TABLE 4.2

MODALITY ANALYSIS Of THE SPEECH

\begin{tabular}{|c|c|c|c|c|c|c|c|c|c|c|c|}
\hline \multirow[t]{2}{*}{ Text } & \multirow{2}{*}{$\begin{array}{l}\text { Total } \\
\text { No. }\end{array}$} & \multicolumn{3}{|c|}{ Low value } & \multicolumn{3}{|c|}{ Median value } & \multicolumn{3}{|c|}{ High value } & \\
\hline & & Positive & Negative & Total & Positive & Negative & Total & Positive & Negative & Total & $\begin{array}{l}\text { Total } \\
\text { percent }\end{array}$ \\
\hline 1 & 4500 & 12 & 1 & 13 & 29 & 3 & 32 & 17 & 6 & 23 & 68 \\
\hline
\end{tabular}


The above table (4.2) showcases the frequency and percentage of modal auxiliaries used by Mr. Trump in his speech. In accordance with the statistics, it is made manifest that modals are employed to relate and refer widely to the orator's perspectives and concepts toward the truth of a proposition/s conveyed by a sentence with an average of $2.22 \%$ throughout the speech. A significant proportion of the exploitation of the modal verbs is adequate and appropriate to the speaking since the speech is delivered through a powerful and political speech. By analogy with other verbs, modals are more readily and easier to spot and then conceded or even acquiesced, the reason for acquiescence and acceptance is that the audience has no time to deliberate at the time of listening to the speech. The most constantly featured modals in the speech are will, must and can indicating the orator's judgments of probabilities, necessity and permission respectively.

\section{Passivization and Nominalization}

Quite a few investigations have provided conclusive findings that political obligations and commitments and the power hierarchy as well in social associations are essential features that determine linguistic strategies such as nominalization and passivization (Kazemian \& Hashemi, 2014, 2017). Linguistically, foregrounding the act of an agent/s, and downgrading and cloaking the agent/s are largely achieved through the deployment of the passive voices and nominalizations. Passivization offers rhetoricians and orators an option to obscure or even eliminate the agent/s altogether in text/talk, known as an Agentlessness structure (Simpson, 1993). In passive clauses, the actors indeed are converted into circumstances, and those circumstances can be removed without making the sentence ungrammatical, e.g.: Nathan was shot to death in the city; grammatically, this clause is an absolutely adequate clause, even though it is Agentless (Renkema, 2009). Undoubtedly, the passive voice foregrounds the theme and backgrounds the agent. Consider some other examples from the speech as follows:

1) We are guided by outcomes, not ideologies.

2) No society could be safe if banned chemical weapons are allowed to spread.

3) The United States has ..., but if it is forced to defend itself or ........

The exertion of all above passivized clauses in his address is probably due to the fact that the effect of the action is much more significant than the actor. In the above excerpts, the agent/s is downgraded in the first example; the action is foregrounded, though; whilst, in the second example, the participant(s) is totally left out to blot out the agent of such foul and obnoxious misdeeds. There is an abundance of nominalized words and 32 passivized phrases in the speech in which the actors are unintendedly 'backgrounded' or cleared away to cloak in actors and/or misdeed. Hence, it can be asserted that such toolkit encrypts ideological bias in favor. In the meanwhile, actors and entities accountable for maltreatment are relegated and hidden from the stage of misdeed or action by orators, and from the crowd or readers as follows (Kazemian \& Hashemi, 2014, 2017):

4) For too long the American people were told that mammoth, .......

5) ... that new generations of children are raised free from violence, hatred, and fear.

6) Their democratic institutions are being destroyed.

7) I was elected not to take power, but to give ........

8) If this is not twisted enough, now North Korea's reckless ........

Fairclough (2003) demystifies that "the exclusion and inclusion of social actors can be syntactically distorted" (p. 149). He comments "there are many motivations for exclusion, such as redundancy or irrelevance, but exclusion may be politically or socially significant" (p. 149). In parallel with the agentlessness of propositions, orators and spin doctors can draw on nominalized phrases to contract and condense information and to obliterate agents out of the scene and make clauses objectified and more equivocal (Cook, 2003) (... free from violence, hatred, and fear from example 5).

\section{Unification Strategy (We-Groups)}

If one pores over a text or listens to a political speech critically and methodically, he/she can fathom how every clause or sentence is delicately engineered for grass roots consumption and how it holds and embodies hidden meanings, underlying assumptions, and strategies awaiting to be revealed and to be spotted by thoughtful audience and observant readers. Unification strategy is one of those prominent techniques utilized by politicians and rhetoricians in political text/talk; the planned deployment of we-groups (we, our and us) serves to create an affiliated relations between orators and the audience. Fairclough (1989) claims that pronouns in English have complementary values of assorted types, that is, the selection between we and you is engaged with combination of 'power and solidarity'. In general, there seems to be two sorts of we-groups, i.e., in inclusive we the audience and orators are incorporated and integrated, simply put, they are strategically unified; nevertheless, in exclusive we the audience is cunningly segregated and dissociated, and it does not incorporate the addressee(s) (Fairclough, 1989). It has been argued that strategic deployment of we-groups in political discourses not only functions to establish a 'personalized/demarginalized and inclusive' linkage between orators and the audience, but also considering its equivocacy, it serve to 'exclude, marginalized/depersonalize' agents of political action making it enigmatic to realize the precise referents of $w e$ in propositions as follows (Fairclough, 2001; Kazemian, 2015):

1) To overcome the perils of ..., we must begin with the wisdom of the past. Our success depends on a ....... We do not expect diverse countries to ....., but we do ... 
2) If we desire to lift up our citizens, if we aspire to the approval of history, then we must fulfill our sovereign duties to the people we faithfully represent. We must protect our nations, their interests and their futures. We must .... We must uphold respect .....

In the above examples $(1 \& 2)$, all we-groups can be categorized under inclusive we in which the speaker makes an effort to include himself with audience and to establish a unified relationship with them. In this regard, he has strategically coalesced and combined himself in the same group to reduce his gap between them, and then to transmit and share his politically creeds and notions to them.

TABLE 4.3

FREQUENCY OF WE-GROUPS IN MR. TRUMP’S SPEECH

\begin{tabular}{|c|c|c|c|c|c|c|c|c|c|c|c|}
\hline \multirow{2}{*}{ Text } & \multirow{2}{*}{$\begin{array}{l}\text { Total } \\
\text { No. }\end{array}$} & \multicolumn{9}{|c|}{ RКEQUENC Y UF WE-UKUUPS IN NHK. I KUMIP S SPEECH } & \\
\hline & & We & Total & Percent & Our & Total & Percent & Us & Total & percent & $\begin{array}{l}\text { Total } \\
\text { percent }\end{array}$ \\
\hline 1 & 4500 & $\sqrt{ }$ & 90 & $2 \%$ & $\sqrt{ }$ & 65 & $1.4 \%$ & $\sqrt{ }$ & 15 & $0.3 \%$ & $3.7 \%$ \\
\hline
\end{tabular}

Knowing the starring roles of we-groups in demonstrating his solidarity with the audience, as table 4.3 displays, Mr. Trump would rather we-groups in his speech more than other pronouns. In the following example (3), he marks and builds political boundaries between his administration/himself or his country, as an authority, and the audience by exclusive we-groups:

3) In Syria and Iraq, we have made .... In fact, our country has achieved ...... We seek the de-escalation of ....

4) ... when we looked around and understood that we were a nation. We realized who we were, what we valued, and what we would give our lives to defend.

5) We want harmony .... We are guided ... We have a policy of .... That realism forces us to confront ..., it is a question we cannot escape or avoid. We will slide down ....., or do we have enough strength and .......

As it is obvious in most above instances (example 5 in particular), there is a vagueness/enigma in the strategy, because at times it is not immediately obvious that by we, who he touches on: is it inclusive or exclusive? It is not immediately apparent by ' $w e$ ' if he incorporates the audience or just leaves them out and embraces his Cabinet and the US. In the above example (4), the usage of we-groups definitely refers to his government and Americans; but in example (3), for instance, he probably unifies himself with the crowd. The unification strategy, i.e., we, our and us are deployed 170 times in the speech $(90,65 \& 15$ times respectively about $3.7 \%$ ) and they are some of the most frequently featured words of the speech.

\section{B. Rhetorical Tropes}

Obviously, research in rhetoric deals with the various forms and powers of political persuasions and this exhortation is noticeably a type of demonstration. A Rhetorical probe in a speech full of rhetorical phrases inquiries into its eloquence, persuasiveness, effectiveness, and contrasting strategies etc. in the realm of political contexts.

\section{Parallelism and Anaphora}

To Gandio (2008), persuasion consists primarily of 3 steps: it can modify, reinforce and constitute someone's notion. Language establishes our understanding, our attitudes, and our orientation to the world; to put it simply, language encompasses discernment and viewpoints. Utilized for persuasive impact and partly for aesthetic splendor and effect, rhetorical devices viz parallelism \& anaphora include instances of Lexico-Syntactic Patterns of language; they also append melody, coherence, and cohesion to any text/talk (Kazemian \& Hashemi, 2014, 2017). Technically, parallelism is "re-occurrence syntactical and lexical similarities and is employed across or inside sentences or even inside clauses and phrases" to show that the ideas in the parts or sentences are equal in importance (Cuddon, 2012, p. 512). And Anaphora is "a rhetorical device involving the repetition of a word or group of words in successive phrases", clauses or sentences, usually along with parallelism (Cuddon, 2012, p. 35). Like passivization, nominalization and other devices, parallel structures and anaphora are intentionally disseminated through the text by the speaker. Consider some excerpts from the speech:

1) ... to lift millions from poverty, to help our citizens realize their dreams, and to ensure that new generations of children are raised free from violence, hatred, and fear.

2) The success of the United Nations depends upon the independent strength of its members. ... Our success depends on a coalition of strong and independent nations that embrace their sovereignty, to promote security, prosperity, and peace, for themselves and for the world.

3) Strong sovereign nations let diverse countries with different values, different cultures, and different dreams not just coexist, .... Strong sovereign nations let their people ..... And strong sovereign nations allow individuals to ....

4) If we desire to lift up our citizens, if we aspire to the approval of history, then we must fulfill our sovereign duties to the people we faithfully represent. We must protect our nations, their interests and their futures. We must reject threats to sovereignty from the Ukraine to the South China Sea. We must uphold respect for law, respect for borders, and respect for culture, and the peaceful engagement these allow.

All the above examples contain both parallelism and anaphora structures which have been boldfaced or underlined for readers' attention. The tactical use of these parallel structures is obviously for effect and they can create a rhythm 
and establish a pattern, giving readers a contextual framework for understanding the ideas. Done well, parallel structures can convey influence, harmony and power to text/talk.

\section{Three-Part Listing and Amplification}

Thomas \& Wareing (2004) argued that "audiences and speakers seem to find linguistically grouped features, and especially those in threes, aesthetically pleasing" (p. 49). Oratorically, the power of three is one of a substantial number of outstanding rhetorical figures, recognized by rhetoricians, which falls within the purview of the heading of parallelism. Not only does an artful arrangement of these grouped figures (threes) add illumination, coalescence, and beauty to the clauses, but also are they deeply embedded in the brain of the audience. They also construct a so-called 'clap-trap rhythm' that the audience appreciate them as both impressive and accordingly oratorical and political as follows: (Atkinson, 1984; Woods, 2006).

1) The Marshall ....are strong, independent, and free.

2) ... to promote security, prosperity, and peace, ....

3) ... with different values, different cultures, and different dreams not just ...

4) In America, the people govern, the people rule, and the people are sovereign.

As embodied in the above examples, repetition and three-part statements emphasize particular points and make the speech more memorable and catchy for the audience. Mr. Trump's speech is teeming with a wide and impressive array of three-part parallel figures which can be symbolized as 'slogan-like expressions' that are verbalized deliberately to attract and focus the crowd's attention to his political dogma and creed. All these three-part structures in the speech amount to 31 clauses denoting that they cannot be expressed impromptu and must be pre-planned and stage-managed. In addition, the three-part listening is accompanied by amplification device in some clauses as the following examples in boldface. Amplification, as a part of rhetoric and common in orator, is frequently utilized by reiterating a word or a phrase while adding more details to it to obtain a particular impact; it is a rhetorical device in which "language is used to extend or magnify or emphasize" (Cuddon, 2012, p. 30):

5) ... we and all others have a goal - that goal is to help them regain their freedom, recover their country, and restore their democracy.

6) ... substantive for strong, sovereign, and independent_nations, nations that are rooted in the ...., nations that seek allies to befriend, .... of all, nations that are home to men and ... for their countries, their fellow citizens, and for all that is best in the human spirit.

7) Those these beautiful pillars, they are pillars of peace, sovereignty, security, and prosperity.

\section{Antithesis and Expletive}

To Abrams \& Harpham (2009), Antithesis is defined as a "contrast or opposition in the meanings of contiguous phrases or clauses that manifest parallelism" (p. 14). Fundamentally, Antithesis is prevalent in rhetoric and oratory and was particularly favored by rhetoricians and orators. To cuddon (2012), it is "contrasting ideas sharpened by the use of opposite or noticeably different meanings" often juxtaposed in parallel structures (p. 45). By dint of antithesis and in the speech, the speaker can put all his premises in two contrasting directions as in:

1) Rogue regimes represented in this body not only support terror but threaten other ...

2) To put it simply, we meet at a time of both immense promise and great peril. It is entirely up to us whether we lift the world to new heights or let it fall into a valley of disrepair.

3) We do not expect diverse countries to share the same cultures, traditions, or even systems of government, but we do expect all nations to uphold .....

4) I was elected not to take power, but to give power to the American people where it belongs.

5) We want harmony and friendship, not conflict and strife.

6) If the righteous many do not confront the wicked few, then evil will triumph.

Generally, the above antithesis phrases are apposed in the speech to present and highlight conflicting statements and to draw the crowd's attention to distinguish facts from fictions. By this marked contrast, the addressees might be more pensive, receptive and impressionable to his propositions, and as a consequence, much more likely to identify and assent to him. They are often juxtaposed in parallel structure as well.

These antithesis and reversal structures in the speech are intentionally or subconsciously, and strategically paired and apposed to exhibit inconsistent premises and to aid the crowd to differentiate facts from fictions, falsehood from truth and so on (Kazemian \& Hashemi, 2017). Some of the above examples, extracted from the speech, contain antithesis, parallel structure, and an expletive. As a figure of emphasis, the expletive device is a single word or a short phrase occasionally interrupting smooth flow of a speech, and is used to place emphasis on the words instantaneously close to the expletive. Typical examples of the expletives in the speech include: but, in fact, to put it simply, indeed, actually, especially, recently, completely, clearly, in any event, totally, certainly, remarkably etc.

\section{Rhetorical Questions}

The last rhetorical strategy analyzed in the corpus is the utilization of Rhetorical Questions which can assist the speaker to bolster his rhetorical influence and affective force of his oratory. By use of these preplanned rhetorical 
questions in the speech, the speaker is in a supreme bid to steer the audience to the focal issue and to his demands that he wishes to convey to them in the following paragraphs. Consider the following excerpts from the speech:

1) Or do we have enough strength and pride to confront those dangers today, so that our citizens can enjoy peace and prosperity tomorrow?

2) Will they continue down the path of poverty, bloodshed, and terror?

3) Or will the Iranian people return to the nation's proud roots as a center of civilization, culture, and wealth where their people can be happy and prosperous once again?

\section{Lexical and Textual Analysis}

The textual function tackles with language mechanisms which help to give any text/talk coherence and cohesion and "make a living passage different from a random list of sentences" (Wang, 2010). It should be noted that the term lexical analysis mainly refers to delve deeply and critically into the speech and to examine it in detail in terms of its coherency, examples and functions of the most frequent and distinct terms, of purposeful deployment of emotively, religiously, and politically-oriented terminology entrenched in, between or behind lines, of the speakers' tone and mood, and of using quotations etc.

To Foss, Foss, and Trapp (2001), a rhetor “can't possibly make a statement without its falling into some sort of pattern, any consideration of the subject or content of rhetoric also must include a consideration of its form" (p. 194). Conventional form in rhetoric is the expected process utilized to craft rhetoric. To Kazemian et al. (2021), "rhetorical form and content are of equal importance to rhetorical acts. Form is the preliminary thing that the readers encounter a discourse". It is argued that if form cannot tempt and attract the readers' interest, nice as its content may be, it mitigates the chance of attracting its readers' focus and evoking their interest, not to mention acquiring identification and obtaining the communicative goals (Zhou \& Kazemian, 2015).

Overall, the speech is well-organized and it shows high rationality and coherence in terms of arguments and content. It does not contain multiple ambiguous, cloaked and implicit remarks so that it may be easy for the audience to grasp and take the speaker's pre-designed assumptions and conceptions in, and therefore, easy for them to identify and align themselves with the speaker. It may be easy for the speaker as well to embolden the audience to support and embrace his policies. Consider the generic structure of the speech as follows:

1) Addressees: Members in the $72^{\text {nd }}$ Session of United Nations General Assembly.

2) Salutation,

3) The expression of gratitude and honor,

4) A short review of his administration's achievement after the election,

5) An analysis of the contemporary situation in the world,

6) Voicing his concerns about terrorist atrocities, international criminal networks etc. in the world,

7) A short summary of the US' and UN's international duties and accomplishments,

8) Reprimanding some rogue regimes in the UN and deprecating their vile deeds nationwide and worldwide such as North Korea, Iran, etc.

9) Hopes for the beautiful and prosperous future of the world and the US,

10) Resort to God for help and blessing.

As the prologue, he commences his speech by defending the status quo after the election and he gives his administration's accomplishments and major changes in the stock market, unemployment, and investment in military forces and defense etc. In his explosive speech, Mr. Trump declared that If Pyongyang does not halt the advancement and proliferation of its nuclear weapons program, the US might have no alternative but to thoroughly annihilate North Korea; in seldom tone and language seen or heard at what is, the head of world diplomacy, Mr. Trump disregarded the proprieties and addressed North Korean leader Kim Jong-un as a rocket man: "Rocket man is on a suicide mission for himself and his regime". He announced that North Korea has maximized testing of ballistic missiles and nuclear payloads, "threatens the entire world with unthinkable loss of life". "If the righteous many don't confront the wicked few, then evil will triumph", he pontificated on. He also discussed that Iran nuclear deal, among the top issues, "was one of the worst and most one-sided transactions the United States has ever entered into".

While poring over the political address, the researchers detected that the speech is replete with some-recurrentlyutilized words or clauses for particular addressees and for specific purposes. Critically, logical and compelling reasons for profuse and plentiful exploitation of selective words in the speech may reflect and be indicative of the speaker's major preoccupations and his growing apprehension about international conflicts, worsening global crises and unrests, and his political ambitions and creed etc. about them as well. For instance, he overtly threatens North Korea and states his attitudes toward that regime by dint of various terms and expression such as 'It is time for North Korea to realize that the denuclearization is its only acceptable future' etc. otherwise it will be totally destroyed by the UN.

$\mathrm{He}$, then, rebuked Iran's government for violence, bloodshed, and chaos; he accused Iranian officials as well of bolstering Bashar al-Assad's dictatorship, of inflaming tensions in Yemen's and its civil war, and of spoiling peace throughout the entire Middle East; his words also insinuate that Iranian government must meet its international responsibilities under UN, otherwise Iran's isolation will be deepened and more sanctions will be enforced. Consider the following frequently featured words in the speech: 
TABLE 4.4

\begin{tabular}{|c|c|c|c|c|c|}
\hline \multicolumn{6}{|c|}{ Most FREQUENTLy USED WORDS IN THE SPEECH } \\
\hline Words & Frequency & Words & Frequency & Words & Frequency \\
\hline Nation & 55 & Freedom & 13 & Power & 9 \\
\hline People & 47 & Peace & 13 & Fight & 8 \\
\hline US & 23 & Politics & 12 & Korea & 8 \\
\hline World & 23 & Future & 12 & History & 8 \\
\hline Prosperous & 20 & Support & 12 & Rights & 8 \\
\hline Sovereign & 19 & American & 11 & Life & 7 \\
\hline Strength & 19 & Iran & 11 & Allies & 7 \\
\hline Regime & 19 & Secure & 11 & Conflict & 7 \\
\hline Human & 17 & Today & 10 & Independent & 7 \\
\hline$U N$ & 15 & Respect & 10 & Values & 7 \\
\hline Terrorist & 14 & Threat & 9 & Hope & 6 \\
\hline Citizen & 14 & Safe & 9 & War & 6 \\
\hline & Positive \& & $l: 438-9.7 \%$ & Negetive: 63 -- & & \\
\hline & & & &. .501 & ntage: $11.13 \%$ \\
\hline
\end{tabular}

Regarding international issues in 2017 viz Iran's and North Korea's nuclear programs, he referred to Iran's name 11 times and North Korea's 8 times, definitely based on his major concerns about them. At first, he is implicitly and then explicitly threatening and alerting North Korea and Iran's government as well to call a halt to their nuclear weapons programme; he accused Iran of shoring up terrorist groups such as Hezbollah and Bashar al-Assad's dictatorship, fuelling Yemen's civil war, and undermining peace throughout the entire Middle East.

He then addressed North Korea's government as a rogue and depraved regime which is accountable for "the starvation deaths of millions of North Koreans, and for the imprisonment, torture, killing, and oppression of countless more". He calls for the denuclearization of North Korea as acceptable future otherwise "we will have no choice but to totally destroy North Korea". Based on the featured words in table 4.4, he has utilized more positive words (about $9 \%$ ) than negatives ones $(1 \%)$ in his speech. His tone of speech is very aggressive and belligerent toward Iran and North Korea but soft, lenient and gentle to the others; overall, he employs a more conciliatory tone throughout the speech.

As presented in Table 4.4, his tone is mostly less belligerent for countrywide and global crises and controversial subjects throughout the speech; he prefers to array more positively-loaded terms than negatively-charged ones (applying major God terms 438 times more frequently than Devil terms), formulating his bright strategies to prioritize and put premium on people's 'wellbeing, peace, security, prosperity' etc. Furthermore, as a political speech, his language is perfectly legitimate, for instance, he ceremonially draws upon titles rather than names throughout his address, and focuses on civility and order. All in all, his confident and optimistic mood permeates throughout the speech and his phrases are generally riveting, benevolent, and stimulating where he endeavors to develop rapports among the audience all over his speech; in such and so, he struggles to build up joint intimacy and rapprochement with the addressees and to go through their heads and hearts by means of various tropes (by we-groups for example), which have big values and are the very epitome of political and media discourses.

Another eye-catching and notable device is the use of quotations from the US Constitution and some heroic figures in the speech (4 quotes) such as two quotes from President Truman about UN's independence, and a quote from John Adams. Accordingly, Atkins \& Finlayson (2016) state that "quotations are not only a source of authority, but a way of claiming authorization"; by referring to President Truman or using the U.S Constitution at the beginning of his speech, he is principally apt to attain his political trustworthiness and authorization to his assertions or to achieve equality to his speech. The quotations can also be deemed to be flashbacks to furnish nostalgic reminiscence and emotive feelings for the audience and to confirm his propositions by tailoring those quotes to his current statement (Kazemian \& Hashemi, 2017). Last but not least, as Wang (2010) contends: "direct or indirect prayers in the speeches, from Bible, Jesus etc. can all assist the speaker to win the sympathy and supporting of the audience and make the speech full of charisma". Thus, by referring to GOD five times in the speech and blessing all people worldwide, Mr. Trump's religious creed and convictions are readily perceptible.

\section{CONCLUSIONS AND IMPLICATIONS}

Political contexts to date have become the major avenue of research and of data for exploration in the realm of linguistics. The prime motive and compelling rationale behind it is that rhetoricians, orators, and spin doctors attempt to opt for politically correct phrases and politically-loaded notions and terms as they have identified that the preponderance of the people are listening to political texts/talks. Thusly, it can be articulated that investigating political texts/talks would furnish a mirror image of their concepts, presumptions and intentions. Considering political speeches, Schäffner (1996) proposes that political texts/talks mirror political activities and they fulfill a variety of functions linked with these activities. Van Dijk (1997) elucidates that any text/talk made or composed by a politician is a cognizance of his motives and purposes, and has its own function. 
The aim of current study was to probe Donald Trump's First Speech to the UN, about 4500 words, from the point of frequency and functions of some rhetorical and critical strategies and Lexical and Textual Analysis as well to reveal its implicit and explicit meanings and structures as well as to grasp and disclose the effective and dominant principles and tropes utilized in his speech. Some rhetorical tropes and Fairclough's CDA framework are employed to disclose the speaker's dexterous and skilled deployment of these devices in the speech which are closely connected with his overall political intentions.

The current study sought to find out how the language in Mr. Trump's speech has been manipulated to create, convey and enforce powerful political assumptions and ideologies to his audience. This was achieved through various tropes, strategies and devices both in Rhetoric and CDA. Rhetoric and rhetorical tropes analyzed in this study, dealing with both the content and form of the speech, offer an analytical lens to researchers to analyze and concentrate on how politicians and rhetorician struggle to convey themselves accurately and effectually in connection with the subject of writing or speech to the audience. In the meantime, with the primary aim of unmasking relationships among language, society, power, and ideology, CDA and its pertinent strategies in the current study supply a toolkit which enables researchers to unravel structures of power and also disclose ideological dogma and power relations in multiple texts/talks.

\section{Findings of the Research}

In the light of an in-depth analysis of the speech based on some rhetorical tropes and CDA strategies, the researchers have summed up the following findings:

1) The speech abounds with deliberate deployment of both rhetorical devices and CDA strategies;

2) The speech used vigilant lexical choices very shrewdly and deliberately which called the audience attention to burst into rapturous applause at the right time;

3) Therefore, a tendency to utilize more devices and tropes by the speaker can be a valid reason for his diplomatic maneuvers to make his political language influential, eloquent, manipulated, pre-planned, and equivocal as well.

4) It also found that the language of Mr. Trump carried specific cynical and negative attitudes toward some governments such as Iran and North Korea but upbeat and positive views toward other countries.

5) Hence, these cynical and ideologically biased attitudes toward some countries are intentionally engineered to establish and build negative image worldwide and nationwide for those countries.

Ultimately, all these inquired strategies divulge that political texts/talks are not improvised at all, and all lexicogrammatical constructions are politically-loaded and intentionally-charged by spin doctors for political and compelling reasons to smoothly convey predetermined ideas and messages to specific targets in order to win and draw the audience's massive support, and to gain power and authority, and to keep them under control as well.

\section{REFERENCES}

[1] Abrams, M. H., \& Harpham, G. G. (2009). A glossary of literary terms. Boston: Wadsworth Cengage Learning.

[2] Afshar, H. S., \& Movassagh, H. (2016). EAP education in Iran: Where does the problem lie? Where are we heading? Journal of English for Academic Purposes,22, 132-151. https://doi.org/10.1016/j.jeap.2016.04.002

[3] Albtoush, M. A., \& Sahuri, S. S. (2017a). Beyond Predator and Prey: Figuring Corruption through Animal Metaphoric Scenarios in the Jordanian Context. English Language and Literature Studies, 7(2), 110. https://doi.org/10.5539/ells.v7n2p110

[4] Albtoush, M. A., \& Sahuri, S. S. (2017b). Figuring the Shame of Corruption in Jordanian Sociopolitical Discourse through a Range of Creative Metaphorical Scenarios. English Language and Literature Studies, 7(3), 17. https://doi.org/10.5539/ells.v7n3p17

[5] Althusser, L. (1971). Ideology and ideological state apparatuses. In Lenin and Philosophy and Other Essays (pp. 121-173). London, England: Verso.

[6] Amoli, F. A. (2016). The Effect of Fairclough's Approach in Iranian Literacy Texts: Critical Discourse Analysis Perspective. Mediterranean Journal of Social Sciences, 7(4), 658. https://doi.org/10.5901/mjss.2016.v7n4p658

[7] Atai, M. R., \& Nazari, O. (2011). Exploring reading comprehension needs of Iranian EAP students of health information management (HIM): A triangulated approach. System, 39(1), 30-43. https://doi.org/10.1016/j.system.2011.01.015

[8] Atkins, J., \& Finlayson, A. (2016). ‘As Shakespeare so memorably said...': Quotation, rhetoric, and the performance of politics. Political Studies, 64(1), 164-181.

[9] Atkinson, M. (1984). Our masters' voices: The language and body language of politics. London: Psychology Press.

[10] Bazerman, C., \& Prior, P. (Eds.). (2003). What writing does and how it does it: An introduction to analyzing texts and textual practices. London and New York: Routledge.

[11] Bizzell, P. (2003). 'Editing the rhetorical tradition', Philosophy and Rhetoric (36): 109-18.

[12] Bull, P., \& Wells, P. (2002). By invitation only? An analysis of invited and uninvited applause. Journal of Language and Social Psychology, 21, 230-244. doi:10.1177/0261927X02021003002

[13] Bull, P. (2016). Claps and Claptrap: The Analysis of Speaker-Audience Interaction in Political Speeches. Journal of Social and Political Psychology, 4(1), 473-492. doi:10.5964/jspp.v4i1.436

[14] Carreon, J. R., \& Svetanant, C. (2017). What Lies Underneath a Political Speech?: Critical Discourse Analysis of Thai PM's Political Speeches Aired on the TV Programme Returning Happiness to the People. Open Linguistics, 3(1), 638-655. https://doi.org/10.1515/opli-2017-0032

[15] Charteris-Black, J. (2011). Politicians and rhetoric: The persuasive power of metaphor: Palgrave Macmillan.

[16] Corbett, E. P. J. (1990). Classical rhetoric for the modern student. New York: Oxford University Press.

[17] Cuddon, J. A. (2012). A Dictionary of literary terms and literary theory, (5th ed.) London: Penguin books. 
[18] Eggins, S. (2004). An introduction to systemic functional linguistics. New York/ London: Continuum.

[19] Fairclough, N. (1989). Language and power. London: Longman.

[20] Fairclough, N. (1995). Critical Discourse Analysis. London: Longman.

[21] Fairclough, N. (2001). Language and Power. London \& New York: Longman.

[22] Fairclough, N. (2003). Analyzing discourse: Textual analysis for social research. London \& New York: Routledge.

[23] Fairclough, N. (2006). Language and Globalization. London and New York: Routledge.

[24] Fairclough, I., \& Fairclough, N. (2013). Political discourse analysis: A method for advanced students. London: England: Routledge.

[25] Fairclough, N. \& R. Wodak (1997): “Critical Discourse Analysis”. In: T. A. van Dijk (ed.): Discourse Studies: A multidisciplinary introduction. (1997): 258-284.

[26] Flowerdew, J. (2002). Rhetorical strategies and identity politics in the discourse of colonial withdrawal. Journal of Language and Politics, 1(1), 149-180. https://doi.org/10.1075/jlp.1.1.09flo

[27] Gill, A. A., \& Kausar, G. (2017). Game of hope and doubt: critical discourse analysis of pak-china economic corridor. New Horizons, 11(2), 1-109.

[28] Goddard, S. E., \& Krebs, R. R. (2015). Rhetoric, legitimation, and grand strategy. Security Studies, 24(1), 5-36. DOI: $10.1080 / 09636412.2014 .100$

[29] Gramsci, A. (1971). Selections from the prison notebooks. London, England: Lawrence \& Wishart.

[30] Halliday, M. A. K. (1994). An introduction to functional grammar (2nd ed.). London: Edward Arnold.

[31] Halliday, M. A. K., \& Matthiessen, C. M. I. M. (2004). An introduction to functional grammar (3rd ed.). London: Edward Arnold.

[32] Hussein, I. (2016). Critical Discourse Analysis of the Political Speech of the Egyptian President, Abdel Fattah El-Sisi, at the New Suez Canal Inauguration Ceremony. International Journal of Language and Literature, 4(1), 85-106.

[33] Johnson, P. (1981). Effects on reading comprehension of language complexity and cultural background of a text. TESOL Quarterly, 15(2), 169-181.

[34] Jorgensen, M. and Phillips, L. (2002). Discourse analysis as theory and method. London: Sage Publications.

[35] Jost, W. \& Olmsted, W. (2004). A companion to rhetoric and rhetorical criticism. Oxford: Blackwell Publishing.

[36] Kazemian, B., \& Hashemi, S. (2014). Critical discourse analysis of Barack Obama's 2012 speeches: Views from systemic functional linguistics and rhetoric. Theory and Practice in Language Studies (TPLS), 4(6), 1178-1187. DOI:10.4304/tpls.4.6.1178-1187.

[37] Kazemian, B. (2015). [Review of the book Describing discourse: A Practical guide to discourse analysis, by Woods, Nicola, 2006]. Asian Journal of Communication, 25(5), 546-549. https://doi.org/10.1080/01292986.2015.1076991

[38] Kazemian, B., \& Hashemi, S. (2017). A Radical Shift to a Profound and Rigorous Investigation in Political Discourse: An Integrated Approach. International Journal of English Linguistics, 7(3), 115-128. https://doi.org/10.5539/ijel.v7n3p115

[39] Kazemian, B., Qaiwer, S. N., \& Mohammadian, Sh. (2021). Islamification vs. Islamophobia: A Message to the Youth in the Occident: Critical \& Rhetorical Inquiries. Journal of Language Teaching and Learning (JLTR), 12(5), 786-799. DOI: 10.17507/jltr.1205.19.

[40] Li, Y. \& Chen, G (2015). The Application of Identification Strategies in Sci-fi Movie Avatar. International Journal of English Linguistics, 5(2), 123-131. http://dx.doi.org/10.5539/ijel.v5n2p123

[41] Lillian, D. L. (2008). Modality, persuasion and manipulation in Canadian conservative discourse. Critical Approaches to $\begin{array}{lllll}\text { Discourse Analysis across } & \text { Disciplines, } & 2(1), & 1-16 . & \text { Retrieved }\end{array}$ http://www.lancaster.ac.uk/fass/journals/cadaad/volume-2-1/

[42] Mortelmans, T. (2007). Modality in cognitive linguistics. In The Oxford handbook of cognitive linguistics. DOI:10.1093/oxfordhb/9780199738632.013.0033

[43] Murphy, J. M. (2003). "Our mission and our moment": George W. Bush and September 11th. Rhetoric \& Public Affairs, 6(4), 607-632. https://doi.org/10.1353/rap.2004.0013

[44] Renkema, J. (2009). Discourse, of course. An overview of Research in discourse studies. Amsterdam/Philadelphia: Benjamins Publishing.

[45] Rex, J. (2011). The President's War Agenda: A Rhetorical View. Presidential Studies Quarterly 41(1), 93-118. doi:10.1111/j.1741-5705.2010.03832.x

[46] Skarp, S. (2016). Rubbish rules: a critical discourse analysis of neoliberalizing processes in Swedish waste management. Master Thesis Series in Environmental Studies and Sustainability Science.

[47] Schaffner, C. (1996). Editorial Political Speeches and Discourse Analysis. Current Issues in Language and Society, 3(3), 201204.

[48] Schiffrin, D., Tannen, D. \& Hamilton, H. E. (eds.). (2003). The Handbook of Discourse Analysis. Oxford: Blackwell.

[49] Simpson, P. (1993). Language, ideology and point of view. London \& New York: Routledge

[50] Sinha, P. N. \& Jackson, B. (2006). A Burkean Inquiry into Leader-Follower Identification Motives. Journal of Culture \& Organization, 12(3), 233-247. http://dx.doi.org/10.1080/14759550600865966

[51] Taping, M. G., Juniardi, Y., \& Utomo, D. W. (2017). Rhetorical Devices in Hillary Clinton Concession Speech. Journal of English Language Studies, 2(2), 225-240.

[52] Thomas, L., \& Wareing. S. (2004). Language, Society and Power. London: Routledge.

[53] Van Dijk, T. A. (2001). Critical Discourse Analysis. In D. Schiffrin, D. Tannen, \& H. E. Hamilton (eds.). (2003). The Handbook of Discourse Analysis ( $1^{\text {st }}$ ed.) (pp. 352-371). Oxford: Blackwell.

[54] Van Dijk, T. A. (2012). Discourse and knowledge. In J. P. Gee \& M. Handford (eds.). (2012). The Routledge Handbook of Discourse Analysis. (pp. 596-603). London: Routledge.

[55] Van Dijk, T. A. (2013). CDA is NOT a method of critical discourse analysis. Retrieved 19/ 02/ 2016, from http://www.edisoportal.org/debate/115-cda-not-method-critical-discourse-analysis 
[56] Wang, J. (2010). A critical discourse analysis of Barack Obama's speeches. Journal of language teaching and research, 1(3), 254-261. doi:10.4304/jltr.1.3.254-261

[57] Wodak, R., Angouri, J., \& Vaara, E. (2014). Struggles over legitimacy in the Eurozone crisis: Discursive legitimation strategies and their ideological underpinnings. Discourse \& Society, 25(4), 500- 518.

[58] Woods, N. (2006). Describing discourse. New York: Horder Education.

[59] Zhou, Q. \& Kazemian, B. (2015). A Rhetorical Identification Analysis of English Political Public Speaking: John F. Kennedy's Inaugural Address. International Journal of Language and Linguistics. Special Issue: Critical Discourse Analysis, Rhetoric, and Grammatical Metaphor in Political and Advertisement Discourses. 4(1-1), 10-16. DOI: 10.11648/j.ijll.s.2016040101.12

Mahdi Derakhshani is a PhD candidate and was born in Tabriz City, East Azerbaijan Province, Iran in 1991. He obtained his B.A. in English Translation and his M.A. in ELT from Islamic Azad University-Shabestar branch, Iran. Currently, he is the managing director of Noor-e-Eram institute in Tabriz. He has 10 years of experience in TEFL at different language institutes in Tabriz. His major thrust areas of interest are CDA, Rhetoric and Rhetorical Devices, ELT and EFL.

Shatha Naiyf Qaiwer obtained her PhD at the university of Nottingham/UK-School of English. Currently, she is teaching at the University of Baghdad. Her major thrust areas of research interest are CDA, Political Discourse Analysis and Corpus Studies.

Bahram Kazemian is a Ph.D. candidate and was born in Tabriz City, East Azerbaijan Province, Iran in 1979. He obtained his B.A. in English Translation and his M.A. in ELT from the Islamic Azad University-Tabriz branch, Iran. Currently, he is the managing director of Unique Language Center in Tabriz. He has 15 years of experience in TEFL at different language institutes in Tabriz. His major thrust areas of interest are Systemic Functional Linguistics, CDA, Rhetoric and Rhetorical Devices, Appraisal Framework in SFL, Metadiscourse Markers (Hedges, Boosters, etc.), ELT and EFL. He has published several articles, six ISI book reviews and one book based on his areas of interest. He serves as a member of Editorial Boards and Reviewers for various journals.

Shaigeh Mohammadian is an MSc and was born in Tabriz city, East Azerbaijan Province, Iran in 1990. She obtained her degree from Urmia University, Iran. She is currently teaching in Unique Language Centre. Her Major thrust areas of research interest are CDA \& ELT. 